\title{
KONTRIBUSI MP-ASI BISKUIT SUBSTITUSI TEPUNG GARUT, KEDELAI, DAN UBI JALAR KUNING TERHADAP KECUKUPAN PROTEIN, VITAMIN A, KALSIUM, DAN ZINK PADA BAYI
}

\author{
Nurly Qurrota Aini, Yekti Wirawani*) \\ Program Studi Ilmu Gizi Fakultas Kedokteran Universitas Diponegoro \\ J1.Dr.Sutomo No.18, Semarang, Telp (024) 8453708, Email : gizifk@ undip.ac.id
}

\begin{abstract}
Background: Baby biscuit substitution with composite arrowroot, soybean, and orange-fleshed sweet potato flours in biscuit baby is a nutritional status improvement programme for people, by diversificated the local food. Thus, it necessary contribution of baby biscuit with composite arrowroot, soybean, and orange-fleshed sweet potato flours on the infant's required of protein, vitamin A, calcium and zink.

Objective: To analize the effect of arrowroot, soybean, and orange-fleshed sweet potato flours substitution on nutrients content, physical properties and the serving size to determine the contribution of nutrient.

Methods: A completely randomized single factor-experimental study by three group ratio of arrowroot, soybean, and orange-fleshed sweet potato flours substitution, which were K (0\%:0\%:0\%), PI (40\%:15\%:25\%), P2 (30\%: $20 \%: 30 \%)$, dan P3 (35\%:25\%:20\%). Statistical analysis of the nutrients content and physical properties with One Way ANOVA test CI 95\% followed by analysis of Multipel Comparation (Posthoct test).

Results: Arrowroot, soybean, and orange-fleshed sweet potato flours substitution increased the protein, fat, $\beta$ karoten, zink content, water absorption and the degree of hardness on a biscuit. Meanwhile, levels of carbohydrate significantly decreasing. There were no significant difference by calcium content, bulk density and test water brewing compared to the control biscuit. Consumption of one serving of $50 \mathrm{~g}$ biscuit P3 (2 biscuits) could contributed energy 40,63\%, protein $31,31 \%$, vitamin a $31,27 \%$, calcium $62 \%$, and zink $18,75 \%$ in infants.

Conclusion: Biscuit with Arrowroot $35 \%$, soybean $25 \%$, and orange-fleshed sweet potato $20 \%$ flours substitution have seen good physical properties of water absorption and the degree of hardness. Consumption two servings of biscuit could sufficient nutrients except zinc in infants.

Password: baby biscuit; nutrients content; physical properties; arrowroot starch; soybean flour; orange-fleshed sweet potato flours.
\end{abstract}

\begin{abstract}
ABSTRAK
Latar Belakang: MP-ASI biskuit bayi dengan substitusi tepung komposit garut, kedelai, dan ubi jalar kuning merupakan upaya perbaikan gizi masyarakat melalui pendekatan penganekaragaman pangan lokal. Dengan demikian dilakukan penelitian mengenai kontribusi MP-ASI biskuit substitusi pati garut, tepung kedelai, dan tepung ubi jalar kuning terhadap kecukupan protein, vitamin A, kalsium, dan zink pada bayi.

Tujuan: Menganalisis pengaruh substitusi tepung garut, kedelai, dan ubi jalar kuning terhadap kandungan zat gizi dan sifat fisik serta menentukan takaran saji untuk mengetahui kontribusi zat gizi.

Metode: Merupakan penelitian eksperimental rancangan acak lengkap satu faktor pada pembutan MP-ASI biskuit bayi dengan substitusi tepung garut, kedelai, dan ubi jalar kuning yaitu K (0 \%:0 \%:0 \%), PI (40 \%:15\%:25 \%), P2 (30\%: $20 \%: 30 \%$ ), dan P3 (35\%:25\%:20\%). Analisis statistik zat gizi dan sifat fisik menggunakan One Way Anova CI 95\% dilanjutkan dengan analisis Multipel Comparation (Posthoct test).

Hasil: Substitusi tepung garut, kedelai, dan ubi jalar kuning meningkatkan kadar protein, lemak, $\beta$-karoten, zink, daya serap air, dan tingkat kekerasan pada biskuit, sedangkan kadar karbohidrat menurun. Kadar kalsium, densitas kamba dan uji seduh tidak berbeda nyata dengan biskuit kontrol. Konsumsi satu takaran saji biskuit P3 sebesar 50 $g$ (2 keping biskuit) dapat memenuhi energi 40,63\%, protein 31,31\%, vitamin A 31,27\%, kalsium $62 \%$, dan zink $18,75 \%$ pada bayi.

Simpulan: Konsumsi dua takaran saji biskuit dengan substitusi tepung garut $35 \%$, kedelai $25 \%$, dan ubi jalar kuning $20 \%$ dapat memenuhi kecukupan zat gizi bayi kecuali zink. Selain itu, biskuit mempunyai sifat fisik yang baik dilihat dari daya serap air dan tingkat kekerasan.
\end{abstract}

Kata Kunci: MP-ASI; kandungan zat gizi; sifat fisik biskuit; pati garut; tepung kedelai; tepung ubi jalar kuning

\section{PENDAHULUAN}

Pemenuhan zat gizi pada bayi dan balita sangat penting untuk pertumbuhan dan perkembangan. Pertumbuhan dan perkembangan yang tidak optimal pada masa balita dapat menyebabkan anak bertubuh pendek (stunting). Hampir sepertiga balita di negara-negara berkembang mengalami stunting dan kebanyakan 
dari mereka defisiensi satu atau lebih zat gizi mikro. Zat gizi mikro yang berkaitan dengan stunting yaitu vitamin A, kalsium, dan zink. ${ }^{1,2}$

Berdasarkan hasil Riset Kesehatan Dasar (Riskesdas) 2010 prevalensi balita stunting untuk skala nasional sebesar 35,6\%, walaupun turun 1,2 $\%$ dibandingkan tahun 2007 (36,8 \%) tetapi belum mencapai target perbaikan gizi Rencana Pembangunan Jangka Menegah Nasional (RPJMN) tahun 2015 sebesar $20 \%$. Angka kejadian stunting jika dilihat berdasarkan kelompok umur, prevalensi stunting pada balita 611 bulan $32,1 \%$ dan meningkat menjadi $41,5 \%$ pada usia $12-23$ bulan. $^{3}$

Faktor yang mempengaruhi terjadinya gangguan tumbuh kembang bayi 6-24 bulan di Indonesia berdasarkan hasil survei Departemen Kesehatan adalah rendahnya mutu MP-ASI dan ketidaksesuaian pola asuh yang diberikan sehingga kecukupan energi dan beberapa zat gizi mikro seperti vitamin A, kalsium, dan zink tidak terpenuhi. Usia 6-24 bulan rawan terjadi kurang gizi karena adanya peningkatan kebutuhan 24-30 $\%$. Oleh karena itu, pada periode ini anak mulai diperkenalkan dengan makanan pendamping air susu ibu (MP-ASI). Penyediaan MP-ASI dengan kepadatan mikronutrien dan frekuensi pemberian yang tepat harus diperhatikan sejak anak berusia 6 bulan untuk mencegah terjadinya stunting. ${ }^{4,5}$

Upaya perbaikan gizi masyarakat dapat dilakukan dengan peningkatan konsumsi pangan melalui pendekatan penganekaragaman pangan. ${ }^{6}$ MP-ASI biskuit bayi biasanya terbuat dari tepung terigu atau tepung beras. Hal ini kurang mendukung penganekaragaman pangan. Gandum sebagai bahan baku terigu merupakan komoditas impor yang hampir tidak diproduksi di Indonesia. ${ }^{7}$ Substitusi terigu dengan tepung komposit bertujuan untuk meningkatkan kandungan zat gizi dan memperbaiki sifat fisik bahan. ${ }^{8}$ MP-ASI banyak dipasarkan dalam bentuk bubur dan biskuit. Bentuk biskuit dapat melatih bayi untuk belajar manggenggam dan menggigit serta mempunyai daya rehidrasi sehingga dapat diencerkan menjadi bubur bayi. ${ }^{9}$

Tepung komposit dalam penelitian ini merupakan campuran dari tepung garut, kedelai, dan ubi jalar kuning. Tepung garut dipilih karena mempunyai sifat dan kandungan zat gizi yang tidak jauh berbeda dengan tepung terigu maupun beras giling. Daya cerna pati yang tinggi sebesar $84,35 \%$, kadar amilosa yang rendah sebesar $29,67-31,34 \%$, dan daya kembang yang tinggi 54 $\%$ menjadikan biskuit lebih lembut, renyah, dan mudah dicerna. Namun, Kadar protein relatif rendah sehingga perlu ditambahkan sumber protein untuk melengkapi kandungan zat gizi pada MPASI. $^{10}$

Salah satu bahan pangan lokal sumber protein yang dapat dimanfaatkan sebagai bahan MP-ASI adalah kedelai karena harganya murah dan mudah didapat. Kadar proteinnya cukup tinggi yaitu 35-38 \% dan dalam bentuk tepung 41,7\% . Pembuatan kedelai menjadi tepung meningkatkan daya cerna protein karena mengurangi zat antinutrisi seperti asam fitat dan antitripsin. ${ }^{10}$ Selain kadar proteinnya yang tinggi, kedelai juga mengandung kalsium dan zink yang cukup tinggi sehingga dapat melengkapi zat gizi pada MPASI. ${ }^{11}$ Protein yang tinggi pada tepung kedelai meningkatkan daya serap air pada biskuit sehingga biskuit lebih tahan saat disimpan. Namun, peningkatan protein juga menyebabkan tekstur biskuit keras. Penelitian sebelumnya maksimal substitusi tepung kedelai pada pembuatan biskuit MP-ASI sebesar $25 \% .^{12}$

Kadar vitamin A pada MP-ASI dapat ditingkatkan dengan pengkayaan menggunakan ubi jalar kuning. Tanaman yang merupakan umbiumbian ini kaya akan $\beta$-karoten. $\beta$-karoten merupakan pro-vitamin $A$ yang terdapat pada makanan nabati, dimana $6 \mu \mathrm{g} \beta$-karoten setara dengan $1 \mu \mathrm{g}$ retinol (bentuk aktif vitamin $\mathrm{A}$ ). ${ }^{13}$ Tepung ubi jalar kuning mengandung $\beta$-karoten $250-500 \mu \mathrm{g} / 100 \quad$ g. Penelitian sebelumnya menunjukkan bahwa substitusi tepung ubi jalar kuning sebanyak $20 \%$ pada pembuatan roti manis akan meningkatkan kadar $\beta$-karoten 12,1\%. Substitusi tepung ubi jalar kuning selain meningkatkan kadar vitamin A juga dapat menjadikan biskuit mudah larut dan mudah dicerna karena kandungan gula reduksi yang bersifat higroskopis. ${ }^{14,15}$

Berdasarkan latar belakang tersebut maka dilakukan penelitian mengenai kontribusi MP-ASI biskuit substitusi tepung garut, kedelai, dan ubi jalar kuning terhadap kecukupan protein, vitamin A, kalsium, dan zink pada bayi.

\section{METODE}

Penelitian yang dilakukan ditinjau dari segi keilmuan termasuk dalam bidang food production. Penelitian ini dilaksanakan mulai bulan Juni hingga Juli 2013 di Laboratorium Ilmu Pangan Universitas Katolik Soegijapranata Semarang.

Penelitian ini termasuk penelitian eksperimental dengan rancangan acak lengkap satu faktor yaitu tepung komposit yang terdiri dari 
tepung garut, kedelai, dan ubi jalar kuning untuk mensubstitusi tepung terigu pada MP-ASI biskuit bayi. Tepung garut dan tepung kedelai berasal dari produk 'GASOL' kemasan 200 g/bungkus. Sedangkan tepung ubi jalar kuning bersal dari PT Rejeki Berkah Sabrangan Gunungpati.

Bahan baku dalam pembuatan biskuit yaitu kuning telur $12,9 \%$, susu skim $12,9 \%$, margarin $25,8 \%$, gula halus $12,9 \%$, dan tepung $55 \%$. Biskuit dibuat dengan metode krim dimana gula halus, margarin, kuning telur, dan bahan pengembang dicampur terlebih dahulu kemudian ditambahkan tepung dan susu skim. Kemudian, adonan yang sudah tercampur rata dicetak dan dipanggang dalam oven $160{ }^{\circ} \mathrm{C}$ selama $20-25$ menit.

Terdapat empat formulasi berupa biskuit kontrol dan biskuit dengan substitusi. Formulasi dalam penelitian ini dapat dilihat pada Tabel 1 .

Tabel 1. Formulasi MP-ASI Biskuit Bayi Subtitusi Tepung Garut, Kedelai, dan Ubi Jalar Kuning

\begin{tabular}{lcccc}
\hline Formulasi & \multicolumn{4}{c}{ Jenis Bahan } \\
\cline { 2 - 5 } & Tepung terigu & Tepung garut & Tepung kedelai & $\begin{array}{c}\text { Tepung ubi } \\
\text { jalar kuning }\end{array}$ \\
\hline Kontrol & $100 \%$ & $0 \%$ & $0 \%$ & $0 \%$ \\
P1 & $20 \%$ & $40 \%$ & $15 \%$ & $25 \%$ \\
P2 & $20 \%$ & $30 \%$ & $20 \%$ & $30 \%$ \\
P3 & $20 \%$ & $35 \%$ & $25 \%$ & $20 \%$ \\
\hline
\end{tabular}

Persentase substitusi tepung garut, kedelai, dan ubi jalar kuning ditentukan berdasarkan estimasi perhitungan total energi, protein, dan serat dari bahan baku pembuatan biskuit yang memenuhi syarat MP-ASI. Persyaratan MP-ASI berdasarkan Surat Keputusan Mentri Kesehatan RI Nomer: 224/Menkes/SK/II/2007 dalam 100 gram biskuit harus mengandung energi minimal 400 kkal, protein 8-12 g, dan maksimal serat 5 g. ${ }^{16}$ Setiap formulasi dilakukan 3 kali pengulangan.

Data yang dikumpulkan dari variabel terikat adalah data kandungan zat gizi dan sifat fisik. Kandungan zat gizi meliputi kadar protein dengan metode Kjeldahl, ${ }^{17}$ lemak dengan metode Soxhlet, karbohidrat dengan metode perhitungan karbohidrat by difference, energi biskuit diperoleh dengan mengkonversi jumlah protein, lemak, dan karbohidrat menjadi jumlah energi, $\beta$-karoten dianalisis menggunakan metode Spektrofotometer, dan kalsium dan zink menggunakan metode Atomic Absorption Specthrophotometer (AAS). ${ }^{18}$ Sementara itu, takaran saji ditentukan berdasarkan pemenuhan 1/3 kecukupan protein bayi dalam sekali konsumsi. Kontribusi per takaran saji MPASI Biskuit bayi ditentukan berdasarkan hasil analisis kadar energi, protein, kalsium, dan zink dibandingkan dengan AKG (Angka Kecukupan Gizi) bayi 7-12 bulan. ${ }^{19,20}$

Sifat fisik meliputi densitas kamba yang merupakan perbandingan antara berat dan volume biskuit, daya serap air ditentukan berdasarkan selisih berat basah dengan berat awal dibandingankan dengan berat sempel pada kadar air $14 \%$, uji seduh merupakan banyaknya air yang dibutuhkan untuk merehidrasi biskuit, dan uji tekstur pada penelitian ini menganalisis tingkat kekerasan (hardness) biskuit dengan menggunakan Texture analyzer. ${ }^{21}$ Analisis data kandungan zat gizi dan sifat fisik biskuit diuji menggunakan One Way Anova dengan derajat kepercayaan $95 \%$ yang dilanjutkan dengan analisis Multipel Comparation (Posthoc test) untuk mengetahui beda nyata antar formulasi.

\section{HASIL}

\section{A. Kandungan dan Kontribusi Zat Gizi MP- ASI Biskuit Bayi}

Kandungan zat gizi yang dianalisis adalah kadar protein, lemak, karbohidrat, energi, $\beta$ karoten, kalsium, dan zink. Hasil analisis kandungan zat gizi pada biskuit substitusi tepung garut, kedelai, dan ubi jalar kuning dapat dilihat pada Tabel 2 berikut. 
Tabel 2. Rerata Kandungan Zat Gizi MP-ASI Biskuit Bayi Substitusi Tepung Garut, Kedelai, dan Ubi Jalar Kuning

\begin{tabular}{|c|c|c|c|c|}
\hline \multirow{2}{*}{ Kadar Zat Gizi } & \multicolumn{4}{|c|}{ Formulasi } \\
\hline & $\mathrm{K}$ & P1 & P2 & P3 \\
\hline Protein (\%) & $8,61 \pm 0,21^{\mathrm{c}}$ & $9,10 \pm 0,04^{\mathrm{bc}}$ & $9,50 \pm 0,31^{\mathrm{ab}}$ & $10,02 \pm 0,38^{a}$ \\
\hline Lemak (\%) & $26,13 \pm 0,31^{b}$ & $27,59 \pm 1,36^{\mathrm{ab}}$ & $28,18 \pm 0,60^{\mathrm{a}}$ & $28,98 \pm 0,07^{a}$ \\
\hline Karbohidrat (\%) & $57,04 \pm 0,99^{\mathrm{a}}$ & $55,22 \pm 2,03^{\mathrm{ab}}$ & $53,11 \pm 0,52^{\mathrm{b}}$ & $52,86 \pm 0,49^{b}$ \\
\hline Energi (kkal/100 g) & $497,77 \pm 1,36^{\mathrm{b}}$ & $505,53 \pm 4,62^{a}$ & $504,08 \pm 2,41^{a b}$ & $512,30 \pm 3,27^{a}$ \\
\hline$\beta$-karoten $(\mathrm{mg} / 100 \mathrm{~g})$ & $0,033 \pm 0,004^{\mathrm{c}}$ & $0,099 \pm 0,02^{\mathrm{b}}$ & $0,153 \pm 0,27^{\mathrm{a}}$ & $0,064 \pm 0,016^{\mathrm{c}}$ \\
\hline Kalsium $(\mathrm{mg} / 100 \mathrm{~g})$ & $\begin{array}{l}247,33 \pm 26,6 \\
5\end{array}$ & $\begin{array}{l}266,67 \pm 37,4 \\
3\end{array}$ & $287,67 \pm 82,04$ & $\begin{array}{l}310,00 \pm 67,6 \\
4\end{array}$ \\
\hline Zink (mg/100 g) & $0,80 \pm 0,12^{\mathrm{c}}$ & $0,90 \pm 0,12^{\mathrm{bc}}$ & $1,29 \pm 0,23^{\mathrm{ab}}$ & $1,50 \pm 0,17^{\mathrm{a}}$ \\
\hline
\end{tabular}

Keterangan: angka yang diikuti dengan huruf superscript berbeda $(\mathrm{a}, \mathrm{b}, \mathrm{c}, \mathrm{d})$ menunjukkan beda nyata $(p<0,005)$

Berdasarkan Tabel 2 di atas, substitusi tepung garut, kedelai, dan ubi jalar kuning pada MP-ASI biskuit bayi secara signifikan meningkatkan kadar protein, lemak, dan zink, sedangkan kadar karbohidrat menurun. Kadar kalsium biskuit substitusi tepung garut, kedelai, dan ubi jalar kuning tidak berbeda nyata dengan biskuit kontrol. Biskuit P3 mempunyai kadar protein, lemak, energi, kalsium, dan zink tertinggi. Namun, mempunyai kadar karbohidrat dan $\beta$ karoten lebih rendah dibandingkan biskuit $\mathrm{P} 1$ dan P2.
Takaran saji ditentukan dari biskuit P3 dengan kadar protein tertinggi yaitu 10,02\%. Takaran saji biskuit P3 untuk memenuhi 1/3 kecukupan protein bayi sebesar $16 \mathrm{~g}$ adalah $50 \mathrm{~g}$ (2 keping biskuit). Kontribusi per takaran saji MPASI Biskuit bayi ditentukan berdasarkan hasil analisis kadar energi, protein, kalsium, dan zink dibandingkan dengan AKG (Angka Kecukupan Gizi) bayi 7-12 bulan. ${ }^{20}$ Kontribusi per takaran saji MP-ASI Biskuit bayi substitusi tepung garut, kedelai, dan ubi jalar kuning terhadap kecukupan zat gizi bayi dapat dilihat pada Tabel 3 berikut.

Tabel 3. Kontribusi per Takaran Saji MP-ASI Biskuit Bayi Substitusi Tepung Garut, Kedelai, dan Ubi Jalar Kuning Terhadap Kecukupan Zat Gizi Bayi 7-12 bulan

\begin{tabular}{|c|c|c|c|c|c|c|}
\hline $\begin{array}{l}\text { Form } \\
\text { ulasi }\end{array}$ & & Energi & $\begin{array}{l}\text { Protei } \\
\mathrm{n}\end{array}$ & $\begin{array}{l}\text { Vitamin } \\
\text { A }\end{array}$ & Kalsium & Zink \\
\hline \multirow[t]{3}{*}{ K } & $\begin{array}{l}\text { Kadar per takaran } \\
\text { saji }\end{array}$ & $248,88 \mathrm{kkal}$ & $4,30 \mathrm{~g}$ & $122,5 \mu \mathrm{g}$ & $\begin{array}{l}123,66 \\
\mathrm{mg}\end{array}$ & $0,40 \mathrm{mg}$ \\
\hline & AKG & $625 \mathrm{kkal}$ & $16 \mathrm{~g}$ & $400 \mu \mathrm{g}$ & $250 \mathrm{mg}$ & $4 \mathrm{mg}$ \\
\hline & \% kecukupan gizi & 39,82 & 26,87 & 30,62 & 49,46 & 10 \\
\hline \multirow[t]{3}{*}{$\mathrm{P} 1$} & $\begin{array}{l}\text { Kadar per takaran } \\
\text { saji }\end{array}$ & $252,76 \mathrm{kkal}$ & $4,55 \mathrm{~g}$ & $128 \mu \mathrm{g}$ & $\begin{array}{l}133,33 \\
\mathrm{mg}\end{array}$ & $0,45 \mathrm{mg}$ \\
\hline & $\mathrm{AKG}$ & $625 \mathrm{kkal}$ & $16 \mathrm{~g}$ & $400 \mu \mathrm{g}$ & $250 \mathrm{mg}$ & $4 \mathrm{mg}$ \\
\hline & \% kecukupan gizi & 40,44 & 28,44 & 32 & 53,33 & 11,25 \\
\hline \multirow[t]{3}{*}{$\mathrm{P} 2$} & $\begin{array}{l}\text { Kadar per takaran } \\
\text { saji }\end{array}$ & $252,04 \mathrm{kkal}$ & $4,75 \mathrm{~g}$ & $132,55 \mu \mathrm{g}$ & $\begin{array}{l}143,83 \\
\mathrm{mg}\end{array}$ & $0,64 \mathrm{mg}$ \\
\hline & AKG & $625 \mathrm{kkal}$ & $16 \mathrm{~g}$ & $400 \mu \mathrm{g}$ & $250 \mathrm{mg}$ & $4 \mathrm{mg}$ \\
\hline & \% kecukupan gizi & 40,32 & 29,68 & 33,14 & $\mathbf{5 7 , 5 3}$ & 16,12 \\
\hline \multirow[t]{3}{*}{ P3 } & $\begin{array}{l}\text { Kadar per takaran } \\
\text { saji }\end{array}$ & 253,94 kkal & $5,01 \mathrm{~g}$ & $125,11 \mu \mathrm{g}$ & $155 \mathrm{mg}$ & $0,75 \mathrm{mg}$ \\
\hline & $\mathrm{AKG}$ & $625 \mathrm{kkal}$ & $16 \mathrm{~g}$ & $400 \mu \mathrm{g}$ & $250 \mathrm{mg}$ & $4 \mathrm{mg}$ \\
\hline & \% kecukupan gizi & 40,63 & 31,31 & 31,27 & 62 & 18,75 \\
\hline
\end{tabular}

Biskuit P3 mempunyai kontribusi kecukupan energi, protein, kalsium, dan zink tertinggi. Namun, kontribusi vitamin A lebih rendah dibandingkan biskuit P1 dan P2. Konsumsi 
satu takaran saji biskuit $\mathrm{P} 3$ dapat memenuhi energi $40,63 \%$, protein $31,31 \%$, vitamin A $31,27 \%$, kalsium $62 \%$, dan zink 18,75\%.

\section{B. Sifat Fisik MP-ASI Biskuit Bayi}

Sifat fisik biskuit dianalisis berdasarkan densitas kamba, daya serap air, uji seduh, dan uji tekstur. Hasil analisis sifat fisik biskuit dapat dilihat pada Tabel 4 berikut.

Tebel 4. Rerata Sifat Fisik MP-ASI Biskuit Bayi Substitusi Tepung Garut, Kedelai, dan Ubi Jalar Kuning

\begin{tabular}{lcccc}
\hline \multirow{2}{*}{$\begin{array}{l}\text { Form } \\
\text { ulasi }\end{array}$} & $\begin{array}{c}\text { Densitas kamba } \\
(\mathrm{g} / \mathrm{ml})\end{array}$ & $\begin{array}{c}\text { Daya serap air } \\
(\%)\end{array}$ & $\begin{array}{c}\text { Uji seduh } \\
(\mathrm{ml})\end{array}$ & \multirow{2}{*}{ Uji Tekstur $(\mathrm{gf})$} \\
\hline $\mathrm{K}$ & $0,63 \pm 0,06$ & $110,00 \pm 3,43^{\mathrm{b}}$ & $35 \pm 5$ & $508,00 \pm 100,80^{\mathrm{b}}$ \\
$\mathrm{P} 1$ & $\mathbf{0 , 6 1} \pm \mathbf{0 , 0 2}$ & $112,73 \pm 7,48^{\mathrm{b}}$ & $30 \pm 5$ & $935,97 \pm 210,35^{\mathrm{a}}$ \\
$\mathrm{P} 2$ & $0,63 \pm 0,03$ & $122,27 \pm 5,07^{\mathrm{b}}$ & $\mathbf{2 5} \pm \mathbf{5}$ & $1024,24 \pm 95,79^{\mathrm{a}}$ \\
$\mathrm{P} 3$ & $\mathbf{0 , 6 2} \pm \mathbf{0 , 0 4}$ & $\mathbf{1 3 8 , 0 3} \pm \mathbf{5 , 4 8} \mathbf{4 8}^{\mathrm{a}}$ & $35 \pm 5$ & $\mathbf{1 1 5 5 , 0 2} \pm \mathbf{1 4 , 8 5}$ \\
\hline
\end{tabular}

Keterangan: angka yang diikuti dengan huruf superscript berbeda $(a, b, c, d)$ menunjukkan beda nyata $(\mathrm{p}<0,005)$

Uji seduh merupakan banyaknya air yang dibutuhkan untuk merehidrasi biskuit. Uji tekstur pada penelitian ini menganalisis tingkat kekerasan (hardness) biskuit. Berdasarkan Tabel 4 di atas, substitusi tepung garut, kedelai, dan ubi jalar kuning secara signifikan meningkatkan daya serap air dan tingkat kekerasan biskuit. Sementara itu, densitas kamba dan uji seduh tidak berbeda nyata dengan biskuit kontrol.

Biskuit P3 mempunyai daya serap air dan tingkat kekerasan tertinggi (138,03 \% dan 1155,02 gf) sehingga lebih tahan lama saat disimpan dan tidak mudah hancur. Namun, membutuhkan jumlah air untuk merehidrasi biskuit lebih banyak dibandingkan biskuit P1 dan P2. Biskuit P2 membutuhkan jumlah air paling sedikit untuk merehidrasi biskuit yaitu $25 \mathrm{ml}$.

\section{PEMBAHASAN}

\section{A. Kandungan dan Kontribusi Zat Gizi MP-} ASI Biskuit Bayi

1. Kadar Protein

Substitusi tepung garut, kedelai, dan ubi jalar kuning secara signifikan meningkatkan kadar protein. Kadar protein semua biskuit dapat memenuhi spesifikasi MP-ASI biskuit bayi yaitu sebesar 8-12 \%. ${ }^{16}$ Sumber protein dalam pembuatan biskuit sebagian besar berasal dari tepung kedelai yang mempunyai kadar protein 41,7 g/100 g. ${ }^{22}$ Biskuit P3 dengan substitusi tepung kedelai $25 \%$ mempunyai kadar protein tertinggi yaitu 10,02 \% dibandingkan dengan P1 dengan substitusi tepung kedelai $15 \%$ dan $\mathrm{P} 2$ dengan substitusi tepung kedelai $20 \%$.

Kecukupan protein merupakan pertimbangan utama penentuan takaran saji karena protein sangat dibutuhkan bayi untuk proses pertumbuhan. ${ }^{19}$ Takaran saji ditentukan dari biskuit P3 dengan kadar protein tertinggi yaitu 10,02 \%. Takaran saji biskuit P3 untuk memenuhi $1 / 3$ kecukupan protein bayi sebesar $16 \mathrm{~g}$ adalah $50 \mathrm{~g}$ (2 keping biskuit).

Mutu protein pada produk pangan bukan hanya dilihat dari kadar protein tetapi juga kandungan asam amino esensial. Asam amino pembatas antara tepung kedelai, serealia (terigu) dan umbi-umbian (tepung garut dan tepung ubi jalar kuning) adalah lisin, metionin dan leusin. Berdasarkan perhitungan dari data sekunder, jumlah asam amino lisin, metionin, dan leusin biskuit substitusi tepung garut, kedelai, dan ubi jalar kuning dibandingkan dengan pola referensi FAO (Food and Agricultural Organization) sebagai standar kandungan asam amino esensial pada suatu produk pangan dapat dilihat pada Tabel 5 berikut. ${ }^{23,24}$

Tabel 5. Kandungan Asam Amino Lisin, Metionin, dan Leusin MP-ASI Biskuit Bayi Substitusi Tepung Garut, Kedelai, dan Ubi Jalar Kuning Dibandingkan Dengan Pola FAO

\begin{tabular}{lccccc}
\hline \multirow{2}{*}{ Asam amino } & \multicolumn{4}{c}{ Formulasi } & \multirow{2}{*}{ Pola } \\
\cline { 2 - 5 } & $\mathrm{K}$ & $\mathrm{P} 1$ & $\mathrm{P} 2$ & $\mathrm{P} 3$ & FAO \\
\hline Lisin $(\mathrm{mg} / 100 \mathrm{~g})$ & 234,37 & 267,97 & 276,58 & 285,19 & 270 \\
Metionin $(\mathrm{mg} / 100 \mathrm{~g})$ & 138,47 & 118,11 & 118,66 & 119,29 & 144 \\
Leusin $(\mathrm{mg} / 100 \mathrm{~g})$ & 433,75 & 384,96 & 395,38 & 405,81 & 306 \\
\hline
\end{tabular}


Berdasarkan Tabel 5, lisin dan leusin biskuit substitusi tepung garut, kedelai, dan ubi jalar kuning lebih tinggi dibandingkan dengan pola FAO, sedangkan metionin lebih rendah. Biskuit P3 mempunyai kandungan asam amino lisin, metionin dan leusin lebih tinggi dibandingkan biskut P1 dan P2. Namun, kandungan metionin dan leusin lebih rendah dari kontrol. Hal ini dikarenakan kandungan metionin dan leusin pada umbiumbian lebih rendah dari terigu yang merupakan serealia. ${ }^{23}$

\section{Energi}

Substitusi tepung garut, kedelai, dan ubi jalar kuning secara signifikan meningkatkan energi. Energi suatu produk pangan dipengaruhi kadar lemak, protein, dan karbohidrat bahan baku biskuit. Lemak memberikan nilai energi sebesar 9 kkal, sedangkan protein dan karbohidrat memberikan energi sebesar 4 kkal. ${ }^{25}$ Kadar lemak semua biskuit lebih tinggi dari spesifikasi MP-ASI biskuit bayi sebesar 10$18 \%$. Tingginya kadar lemak pada biskuit karena penggunaan margarin yang cukup tinggi yaitu $25,8 \%$. Lemak berfungsi sebagai shortening untuk membentuk tekstur dan cita rasa biskuit sehingga kurangnya penggunaan lemak dapat membuat tekstur biskuit keras. ${ }^{12}$

Bahan baku biskuit yang mengandung lemak tinggi selain margarin adalah kuning telur dan tepung kedelai. Penggunaan margarin dan kuning telur sama pada semua formulasi sehingga peningkatan kadar lemak dipengaruhi oleh persentase substitusi tepung kedelai. Substitusi $15 \%$ tepung kedelai ke dalam formula tepung komposit dengan $20 \%$ tepung garut pada pembuatan mie menghasilkan peningkatan kadar protein dan lemak tetapi menurunkan kadar karbohidrat. ${ }^{15}$ Biskuit P3 dengan kadar lemak dan protein tertinggi mempunyai kadar karbohidrat terendah yaitu 52,86 \% . Walaupun kadar karbohidrat biskuit turun, energi biskuit masih memenuhi spesifikasi MP-ASI biskuit bayi minimal sebesar 400 kkal/100g. ${ }^{16}$

Biskuit P3 mempunyai energi tertinggi yaitu $507,89 \mathrm{kkal} / 100 \mathrm{~g}$. Energi per takaran saji biskuit P3 memberikan kontribusi kecukupan energi sebesar 40,63\%. Berdasarkan penelitian $\mathrm{WHO}$, pemberian ASI yang cukup pada bayi usia 7-12 bulan menyumbang energi sebesar 413 kkal sehingga kecukupan energi dapat terpenuhi dengan pemberian ASI dan konsumsi dua takaran saji biskuit. ${ }^{19}$

\section{Kadar $\beta$-karoten}

Kadar $\beta$-karoten biskuit substitusi tepung garut, kedelai, dan ubi jalar kuning berbeda nyata dengan biskuit kontrol. Sumber $\beta$-karoten pada biskuit sebagian besar berasal dari tepung ubi jalar kuning dengan kadar $\beta$-karoten $250-500 \mu \mathrm{g} / 100 \mathrm{~g}$. ${ }^{14}$ Biskuit P3 dengan substitusi tepung ubi jalar kuning $20 \%$ mempunyai kadar $\beta$-karoten lebih rendah dari biskuit P1 dengan substitusi ubi jalar kuning $25 \%$ dan P2 dengan substitusi ubi jalar kuning $35 \%$. Biskuit P2 mempunyai kadar $\beta$-karoten tertinggi yaitu $153,33 \mu \mathrm{g} / 100 \mathrm{~g}$.

Kadar $\beta$-karoten dapat berkurang dan mengalami kerusakan karena proses pengolahan. Struktur ikatan rangkap $\beta$ karoten mudah teroksidasi pada proses pemanasan suhu tinggi. ${ }^{26}$ Pengolahan roti substitusi tepung ubi jalar kuning dengan proses pemanggangan pada suhu $\pm 160{ }^{\circ} \mathrm{C}$ selama 15 menit menurunkan kadar $\beta$ karoten sebesar $68,5 \%$. Jumlah penurunan semakin besar dengan peningkatan suhu dan waktu pemanggangan. ${ }^{27}$

$\beta$-karoten merupakan pro-vitamin A yang terdapat pada makanan nabati, dimana 6 $\mu \mathrm{g} \beta$-karoten setara dengan $1 \mu \mathrm{g}$ retinol (bentuk aktif vitamin A). Kadar $\beta$-karoten semua biskuit belum memenuhi spesifikasi MP-ASI biskuit bayi yaitu kadar vitamin A minimal sebesar 250-266,7 $\mu \mathrm{g} / 100 \quad \mathrm{~g}^{16}$ Vitamin A bukan hanya dari $\beta$-karoten tetapi juga dari retinol pada produk hewani, dimana pada penelitian ini tidak dapat dianalisis karena hanya melihat kadar $\beta$-karoten. Sumber retinol pada biskuit berasal dari susu skim, kuning telur, dan margarin dengan penggunan $12,9 \%, 12,9 \%$, dan $25,8 \%$. Berdasarkan data sekunder, kadar retinol dari ketiga bahan makanan tersebut secara berturut-turut yaitu $39 \mu \mathrm{g}, 606 \mu \mathrm{g}, 606$ $\mu \mathrm{g} / 100$ g. Jumlah retinol dari ketiga bahan tersebut adalah 239,55 $\mu \mathrm{g} / 100 \mathrm{~g} .{ }^{22}$ Total retinol merupakan penjumlahan retinol dari konversi $\beta$-karoten dengan retinol dari ketiga bahan. Total retinol biskuit dapat dilihat pada Tabel 6 berikut. 
Tabel 6. Total Retinol MP-ASI Biskuit Bayi

\begin{tabular}{lcc}
\hline Formulasi & $\begin{array}{c}\text { Retinol dari konversi } \beta- \\
\text { karoten }(\mu \mathrm{g} / 100 \mathrm{~g})\end{array}$ & Total retinol biskuit $\mu \mathrm{g} / 100 \mathrm{~g} *$ \\
\hline $\mathrm{K}$ & 5,45 & 245 \\
P1 & 16,45 & 256 \\
P2 & 25,55 & 265,1 \\
P3 & 10,67 & 250,22 \\
\hline
\end{tabular}

Keterangan: *hasil penjumlahan retinol dari konversi $\beta$-karoten dengan retinol susu skim, kuning telur, dan margarin $(239,55 \mu \mathrm{g} / 100 \mathrm{~g})$

Berdasarkan Tabel 6 di atas, kadar vitamin A biskuit P3 sudah memenuhi spesifikasi MP-ASI biskuit bayi yaitu minimal $250 \mu \mathrm{g} / 100 \mathrm{~g}$. Kadar vitamin A per takaran saji biskuit P3 memberikan kontribusi kecukupan $31,27 \%$. Kontribusi vitamin A dari MP-ASI minimal $60 \%$ dari AKG sebesar $400 \mu \mathrm{g} / 100$ g. ${ }^{16}$ Konsumsi dua takaran saji biskuit sudah memenuhi kecukupan vitamin A bayi.

4. Kadar Kalsium dan Zink

Kadar kalsium biskuit substitusi tepung garut, kedelai, dan ubi jalar kuning tidak berbeda nyata dengan biskut kontrol. Semua biskuit dapat memenuhi spesifikasi kadar kalsium MP-ASI biskuit bayi sebesar 200-400 $\mathrm{mg} / 100$ g. Sementara itu, substitusi tepung komposit secara signifikan meningkatkan kadar zink biskuit. Walaupun kadar zink meningkat, belum memenuhi spesifikasi MP-ASI biskuit bayi sebesar 2,5-3,0 mg/100 g. ${ }^{16}$

Sumber kalsium dan zink pada biskuit berasal dari susu skim, kuning telur, dan tepung kedelai. Jumlah Susu skim dan kuning telur yang digunakan sama pada semua formulasi sehingga yang mempengaruhi peningkatan kalsium dan zink adalah tepung kedelai. Tepung kedelai mempunyai kadar kalsium 346 $\mathrm{g} / 100 \mathrm{~g}$ dan zink $4 \mathrm{mg} / 100 \mathrm{~g}{ }^{11}$ Biskuit P3 dengan substitusi tepung kedelai $25 \%$ mempunyai kadar kalsium dan zink tertinggi yaitu $310 \mathrm{mg} / 100 \mathrm{~g}$ dan $1,50 \mathrm{mg} / 100 \mathrm{~g}$. Kadar kalsium dan zink per takaran saji biskuit P3 memberikan kontribusi kecukupan $62 \%$ dan $18,72 \%$. Konsumsi dua takaran saji biskuit sudah memenuhi kecukupan kalsium bayi, sedangkan zink belum tercukupi. Hal ini dikarenakan substitusi tepung kedelai pada biskuit bayi dibatasi karena dapat membuat tekstur biskuit keras. Maksimal substitusi tepung kedelai pada tepung komposit untuk mendapatan tekstur yang masih dapat diterima konsumen sebesar $25 \%{ }^{12}$
Kedelai mengandung faktor antinutrisi seperti antitripsin dan asam fitat yang dapat mengikat mineral terutama kalsium, zink, besi, dan magnesium sehingga bioavailabilitasnya rendah. Antinutrisi dapat menurun dengan adanya proses pemanasan. Penurunan antinutrisi kedelai dapat mencapai $20 \%$ pada proses pemanasan dengan suhu $121{ }^{\circ} \mathrm{C}$ selama 5 menit, kadar antinutrisi akan terus menurun dengan peningkatan waktu pengolahan. Oleh karena itu, faktor antinutrisi bukan merupakan masalah dalam pemanfaatan kacang kedelai sebagai salah satu sumber protein dan penyuplai kalsium dan zink pada MP-ASI. ${ }^{24,28}$

\section{B. Sifat Fisik MP-ASI Biskuit Bayi}

Substitusi tepung garut, kedelai, dan ubi jalar kuning meningkatkan kadar protein pada biskuit. Kadar protein pada biskuit mempengaruhi daya serap air dan tingkat kekerasan biskuit. Daya serap air merupakan salah satu sifat hidrasi protein yaitu kemampuan protein menahan air dalam suatu sistem pangan. Semakin tinggi kadar protein pada biskuit akan meningkatkan daya serap air. Sifat fisik ini berkaitan dengan daya simpan biskuit. Kualitas biskuit yang baik yaitu biskuit dengan daya serap air tinggi sehingga biskuit lebih tahan lama saat disimpan. ${ }^{12}$ Substitusi tepung garut, kedelai, dan ubi jalar kuning secara signifikan meningkatkan daya serap air. Biskuit P3 dengan kadar protein tertinggi $(10,02 \%)$ mempunyai daya serap air tertinggi yaitu $138,03 \%$.

Uji tekstur pada penelitian ini menganalisis tingkat kekerasan (hardness) menggunakan alat Texture analyzer dengan satuan gf (gramforce) yang menunjukkan kekuatan suatu bahan terhadap tekanan. Tingkat kekerasan pada produk biskuit dikaitkan dengan sifat kerenyahan. Kerenyahan biskuit akan semakin menurun dengan naiknya tingkat kekerasan. Biskuit bayi dengan tingkat kekerasan antara 948-1196 gf mempunyai tekstur tidak terlalu keras dan tidak mudah hancur sehingga dapat dijadikan finger food.$^{29}$ Biskuit P3 dengan substitusi $25 \%$ tepung kedelai mempunyai 
tingkat kekerasan tertinggi yaitu 1155,02 gf dan masih memenuhi tingkat kekerasan biskuit bayi.

Kadar protein yang meningkat menyebabkan ketidakseimbangan tepung dalam mengikat air sehingga proses gelatinisasi kurang sempurna. Hal ini menyebabkan meningkatnya kekerasan produk. ${ }^{29}$ Sumber protein dalam pembuatan biskuit sebagian besar berasal dari tepung kedelai dengan kadar protein $41,7 \mathrm{~g} / 100 \mathrm{~g} .{ }^{22}$ Semakin tinggi substitusi tepung kedelai daya serap air dan tingkat kekerasan biskuit meningkat. Dilihat dari daya serap air dan tingkat kekerasan, biskuit P3 mempunyai sifat fisik yang baik karena lebih tahan lama saat disimpan dan tidak mudah hancur sehingga dapat dijadikan finger food. Namun, dilihat dari densitas kamba dan uji seduh biskuit P3 tidak berbeda nyata dengan kontrol.

Densitas kamba menunjukkan perbandingan berat bahan terhadap volumenya. MP-ASI bayi harus bersifat kamba sehingga bayi tidak cepat kenyang karena kapasitas perut yang kecil. ${ }^{29}$ Biskuit P1 dengan substitusi tepung garut $40 \%$ mempunyai densitas kamba terendah yaitu 0,61 $\mathrm{g} / \mathrm{ml}$. Tepung garut mempunyai daya kembang tinggi yaitu $54 \%$ sehingga biskuit bayi mempunyai volume yang besar. ${ }^{27}$ Semakin tinggi substitusi tepung garut meningkatkan volume biskuit sehingga densitas kamba biskuit menurun.

Uji seduh merupakan gambaran rasio rehidrasi antara jumlah air yang ditambahkan dengan jumlah bahan makanan pada setiap penyajian. Biskuit P2 membutuhkan air paling sedikit yaitu $25 \mathrm{ml}$. Jumlah air yang ditambahkan tidak boleh terlalu banyak karena dapat menyebabkan bayi cepat kenyang sebelum energinya tercukupi. Semakin rendah kelarutan biskuit maka semakin sedikit air yang dibutuhkan untuk merehidrasi. ${ }^{29}$

Kelarutan biskuit dapat menurun karena adanya gula reduksi yang bersifat higroskopis. Ubi jalar kuning mengandung gula reduksi sebesar $43,89 \% .{ }^{30}$ Biskuit P2 dengan substitusi ubi jalar kuning $30 \%$ membutuhkan air lebih sedikit dibandingkan biskuit P1 dengan substitusi ubi jalar kuning $25 \%$ dan P3 dengan substitusi ubi jalar kuning $20 \%$. Hal ini menunjukkan bahwa semakin tinggi substitusi tepung ubi jalar kuning kelarutan menurun sehingga lebih sedikit membutuhkan air untuk merehidrasi biskuit.

\section{SIMPULAN DAN SARAN}

\section{A. Simpulan}

Konsumsi dua takaran saji biskuit dengan substitusi tepung garut $35 \%$, kedelai $25 \%$, dan ubi jalar kuning $20 \%$ dapat memenuhi kecukupan zat gizi bayi kecuali zink. Selain itu, biskuit mempunyai sifat fisik yang baik dilihat dari daya serap air dan tingkat kekerasan.

\section{B. Saran}

Biskuit yang direkomendasikan sebagai MPASI adalah biskuit substitusi tepung garut $35 \%$, kedelai $25 \%$, dan ubi jalar kuning $20 \%$ dengan takaran saji $50 \mathrm{~g}$ (2 keping biskuit). Biskuit dikonsumsi dua takaran saji apabila bayi hanya mengkonsumsi ASI.

\section{DAFTAR PUSTAKA}

1. Maria JS, Marcela BZ, Alexis EL, Ricardo AC, Ricardo Weill, Jose RB. The role of zinc in the growth and development of children. Elsevier Science Inc 2002, 18: 510-9.

2. Frances E. Aboud, Sohana Shafique, Sadika Akhter. A Responsive feeding intervention increases children's self-feeding and maternal responsiveness but not weight gain. The Journal of Nutrition 2009, 139: 1738-43.

3. Kementrian Kesehatan Republik Indonesia. Riset Kesehatan Dasar (Riskesdas). Jakarta: Kementrian Kesehatan, 2010.

4. Departemen Kesehatan Republik Indonesia. Pedoman Pemberian Makanan Pendamping ASI. Jakarta: Departemen Kesehatan, 2004.

5. Kementrian Kesehatan Republik Indonesia. Program prioritas tahun 2010-2014 dan capaian program 100 hari. Jakarta: Kementrian Kesehatan, 2010.

6. Ani Kurniawan. Policies in alleviating micronutrient deficiencies: indonesia's experience. Asia Pacific J Clin Nutr 2002, 11(3): S360-70.

7. Erizal M, Afrianto, editor. Tinjauan pasar tepung terigu. Jakarta: Tim Komoditi Spesialis Tepung terigu Kementrian perdagangan republik Indonesia; 2012.

8. Widowati. Tepung aneka umbi sebuah solusi ketahanan pangan. Balai Besar Penelitian dan Pengembangan Pascapanen Pertanian Dimuat dalam Tabloid Sinar Tani 6 Mei 2009; hal 45-7.

9. Nanden Kirana. Finger food kue kecil untuk cemilan. Jakarta: PT Gramedia Pustaka Utama; 2006.

10. Widaningrum, Sriwidowati, Suwarno TS. Pengayaan tepung kedelai pada pembuatan mie basah dengan bahan baku tepung terigu yang disubstitusi tepung garut. J. Pascapanen 2005, 2 (1): 41-8.

11. Michihiro Sugano. Soy in health and disease prevention. Londen: Tayler and Francis Grup; 2006.

12. Dian YS. Studi pengaruh tepung komposit bijibijian dan konsentrasi penstabil terhadap mutu makanan pendamping asi biskuit [Tesis]. 
Sumatra Utara: Program Studi Teknologi Hasil Pertanian Universitas Sumatra Utara; 2010.

13. Murray, Robert K, Daryl K. Granne, Victor WR. Harper's illustrated biochemistry, $27^{\text {th }}$ ed. USA: The McGraw Hill Companies Inc; 2007.p.505-6.

14. Indrie Ambarsari, Abdul Choliq. Rekomendasi dalam penetapan standar mutu tepung ubi jalar. Jurnal Standardisasi 2009, 11 (3): 212-9.

15. Idolo I. Sensory and nutritional quality of madiga produced from composite flour of wheat and sweet potato. Pak J Nutr 2011. 10 (11): 1004-7.

16. Kementrian Kesehatan Republik Indonesia. Keputusan Mentri Kesehatan Republik Indonesia, Nomer: 224/Menkes/SK/II/2007 tentang Spesifikasi teknis makanan Pendamping Air Susu Ibu (MP-ASI). Jakarta: Kementrian Kesehatan, 2007.

17. Dendy DAV, Dobraszczykbj. Cereal and cereal products: chamistry and technology. USA: Springer; 2001.

18. AOAC. Official methods of analysis of the association of official analytical chemistry. Arlington: AOAC Inc; 1995.

19. Dewey KG, Brown KH. Update on technical issues concerning complementary feeding of young children in developing countries and implications for intervention programs. Food and Nutrition Bulletin The United Nations University 2003; $24: 1$.

20. LIPI. Angka Kecukupan Gizi (AKG). Widyakarya Nasional Pangan, 2004.

21. Shiv Kumar, Rekha, Lalan K. Evaluation of quality characteristics of soy based millet biscuits. Pelagia Research Library 2010, 1 (3): 187-96.

22. Mien KM, Nils AZ, editor. Tabel komposisi pangan Indonesia . Jakarta: PT Elex Media Kopuntindo; 2008.

23. Padmaja G. Uses and nutritional data of sweet potato. In: George T, editor. The sweet potato. Berlin: Springer Science, 2009; p.190-199,212.

24. Dedy Muchtadi. Teknik evaluasi nilai gizi protein. Bandung: Alfabeta; 2010.

25. Hadiningsih N. Optimasi formula makanan pendamping asi dengan menggunakan response surface methodology [Tesis]. Bogor: Sekolah Pascasarjana Institut Pertanian Bogor; 2004.

26. Christina Mumpuni Erawati. Kendali stabilitas betakaroten selama proses produksi tepung ubi jalar (Ipomoea batatas L.). [tesis]. Bogor: Sekolah Pascasarjana Institut Pertanian Bogor; 2006.

27. Lisia Yusianti dan Purwiyatno Hariyadi. Kajian formulasi dan proses pemanggangan roti kaya karotenoida dengan substitusi tepung ubi jalar dan minyak sawit. [skripsi]. Bogor: Fakultas Teknologi Pertanian Institut Pertanian Bogor; 2001.
28. Stanijevic, Vucelic R, Barac, Pesic. The effect of autoclaving on soluble protein composition and trypsin inhibitot activity of cracked soybean. APTEFF 2004; 35:48-57.

29. Sri Rebecca S. Pembuatan biskuit untuk makanan sapihan dari tepung garut (Maranta arundinaceae L) [skripsi]. Bogor: Fakultas Teknologi Pertanian Institusi Pertanian Bogor; 2003.

30. Anggita Widhi R. Kajian formulasi cookies Ubi Jalar (Ipomoea batatas L) dengan karakteristik tekstur menyerupai cookies keladi. Bogor: Institut Pertanian Bogor; 2008. 